\title{
PCR-based assays for the fish pathogen Aeromonas salmonicida. I. Evaluation of three PCR primer sets for detection and identification
}

\author{
Helen K. Byers, Nicholas Gudkovs, Mark St. J. Crane*
}

Australian Animal Health Laboratory, CSIRO Livestock Industries, Private Bag 24, Geelong, Victoria 3220, Australia

\begin{abstract}
In an effort to develop a rapid diagnostic test for the fish pathogen Aeromonas salmonicida, the performance of 2 polymerase chain reaction (PCR) primer sets (AP and PAAS) targeting the fish pathogen A. salmonicida and 1 PCR primer set (MIY) targeting A. salmonicida subsp. salmonicida were evaluated. Initially, the PCR assays were used to screen purified DNA extracted from 308 A. salmonicida isolates. The AP and PAAS PCR tests were demonstrated to be $100 \%$ specific for the species A. salmonicida and did not cross-react with any of the non-target organisms (bacterial species other than A. salmonicida) used in this study. The combined sensitivity of the AP and PAAS tests was $99.4 \%$ and offered the best coverage in terms of identifying the target organism. The MIY PCR appeared to be $100 \%$ sensitive and specific for A. salmonicida subsp. salmonicida. Studies with tissues, spiked with known quantities of bacteria, were conducted to determine the lower detection limit of the PCR tests, and then the ability of these PCR tests to detect A. salmonicida in experimentally infected salmonids was assessed.
\end{abstract}

KEY WORDS: Aeromonas salmonicida · Furunculosis · Detection · Identification · Experimental infections $\cdot$ Polymerase chain reaction

\section{INTRODUCTION}

Aeromonas salmonicida is a complex group of bacterial pathogens, many strains of which cause a range of diseases in a wide variety of fish species (Austin \& Austin 1999). A. salmonicida subsp. salmonicida, also known as 'typical A. salmonicida', is the causative agent of furunculosis, an often devastating disease of salmonids (Hiney \& Olivier 1999).

Furunculosis poses a very serious exotic disease threat to the growing salmonid aquaculture industries in Australia. This threat is further complicated by the fact that the bacterium can be present as clinically inapparent or 'covert' infections in 'carrier' fish (Hiney et al. 1997). Carriers can be extremely difficult to detect, due to the fact that Aeromonas salmonicida is likely to be present only in low numbers, and its pri-

${ }^{*}$ Corresponding author. E-mail: mark.crane@csiro.au mary location within the carrier host remains unknown. All of these factors lead to the possibility that A. salmonicida subsp. salmonicida could enter Australia undetected, establish covert infections in fish and become widely disseminated before the first clinical case of furunculosis is reported.

Some atypical strains of Aeromonas salmonicida are already considered enzootic to Australia (Whittington et al. 1995, Trust et al. 1996). The incidence of disease outbreaks caused by atypical strains, not only in Australia but also world-wide, appears to be increasing and could potentially affect both aquaculture and natural fisheries over a wide geographic range within southern Australia. It is essential that the technology to differentiate between those strains exotic to Australia (particularly typical A. salmonicida) and enzootic strains be developed.

Identification of Aeromonas salmonicida, based on traditional methods including classical biochemical 
testing, can be time consuming and problematic. Phenotypic variation displayed by this group of bacteria can make assigning new isolates to the existing taxonomy, based on phenotype, a difficult procedure (Austin et al. 1998). Polymerase chain reaction (PCR) technology may be able to provide a rapid means of identifying and differentiating bacterial isolates that display phenotypic properties that would otherwise hinder their timely identification. Our objective was to develop improved procedures for the detection and identification of A. salmonicida species and subspecies, thus enhancing the diagnostic capability for this fish pathogen.

\section{MATERIALS AND METHODS}

Aeromonas salmonicida isolates. In order to undertake extensive in vitro validation and determination of the specificity and sensitivity of the PCR tests, the Australian Animal Health Laboratory (AAHL) Fish Diseases Laboratory (AFDL) sourced a wide variety of $A$. salmonicida isolates $(n=308)$ from all regions of the world where this species has been isolated (Table 1). The collection comprised type and reference cultures from recognised culture collections, and clinical and laboratory strains originating from at least 38 teleost species. Approximately $85 \%$ of the isolates in the AFDL A. salmonicida collection are exotic to Australia.

Cultures other than Aeromonas salmonicida. A variety of bacterial cultures were employed to test the specificity of the PCR assays. Isolates included representatives of the Aeromonas DNA hybridisation groups (Huys \& Swings 1999) and a range of common fish pathogens (Table 2).

Maintenance of bacterial strains. All bacterial isolates were stored in MicroBank ${ }^{\mathrm{TM}}$ vials (Pro-Lab) at $-80^{\circ} \mathrm{C}$ as per the manufacturer's instructions. When required, isolates were grown on Columbia Blood Agar Base (Oxoid CM331), supplemented with $5 \%$ defibrinated sheep blood, incubated aerobically at $22^{\circ} \mathrm{C}$ for 2 to $4 \mathrm{~d}$.

Biochemical characterisation. To confirm their identity and to group the isolates according to subspecies, a biochemical profile was obtained for 243 of the 308 Aeromonas salmonicida isolates. The profile consisted of the following tests: Gram stain; pigment production on tryptic soy agar (TSA); cytochrome oxidase; motility; growth on sheep blood agar (SBA) at $37^{\circ} \mathrm{C}_{i}$ indole; methyl red; VogesProskauer; arginine dihydrolase (Moeller); nitrate reduction; aesculin hydrolysis; gas production $(1 \%$ carbohydrate in oxidation-fermentation $[\mathrm{OF}]$ basal medium) from D-glucose; and acid production from Larabinose, D-galactose, maltose, D-mannitol, sucrose, and trehalose. Tests were conducted according to Balows et al. (1993) except that cultures were incubated at $22^{\circ} \mathrm{C}$. Tests were examined at $1,2,3,5,7$ and $10 \mathrm{~d}$ post-inoculation. Terminal end-product tests were evaluated 4 to $10 \mathrm{~d}$ post-inoculation.

Genomic DNA extraction. Genomic DNA was extracted from all bacterial isolates using the DNAzol ${ }^{\circledR}$ reagent (Life Technologies ${ }^{\mathrm{TM}}$ ) or the Puregene ${ }^{\circledR}$ DNA Isolation Kit (Gentra Systems) as per the manufacturer's instructions.

PCR protocols. PCRs were performed in $0.2 \mathrm{ml}$ thin-walled PCR tubes (Quantum Scientific) in a GeneAmp ${ }^{\circledR} 9600$ thermal cycler (Perkin Elmer-Cetus). The DNA polymerase and buffering system used was either Taq DNA polymerase from Promega or Platinum $^{\mathrm{TM}}$ Taq from Life Technologies ${ }^{\mathrm{TM}}$. Unless otherwise specified, 1 to $10 \mathrm{ng}$ template DNA was added.

Table 1. List of contributors to the Australian Animal Health Laboratory (AAHL) Fish Diseases Laboratory (AFDL) Aeromonas salmonicida collection

American Type Culture Collection, USA

AAHL Fish Diseases Laboratory

Commonwealth Scientific and Industrial Research Organisation (CSIRO) Livestock Industries, Australia

Australian Fish Health Reference Laboratory, Benalla, Australia

Dr. C. Rogers, Fish Diseases Laboratory, Centre for Environment, Fisheries and Aquaculture Science (CEFAS), UK

Dr. C. Michel, Institut National de la Recherche Agronomique, France

Dr. E. B. Shotts, Department of Microbiology, University of Georgia, USA

Dr. H. Kalnins, Commonwealth Serum Laboratories, Australia

Dr. I. Dalsgaard, Danish Institute for Fisheries and Marine Research, Denmark

Dr. J. Carson, Fish Health Unit, Mt. Pleasant Laboratory, Department of Primary Industries, Water and Environment (DPIWE), Australia

Dr. M. Hiney, Fish Disease Group, University College Galway, Ireland

Dr. O. Haenen, Institute for Animal Science and Health, The Netherlands

Dr. P. Rintamaki, University of Oulu, Finland

Dr. R. Whittington, Elizabeth MacArthur Agricultural Institute, Australia

Dr. R. B. Callinan, NSW Department of Fisheries, Australia

Dr. R. Cipriano, National Fish Health Research Laboratory, USA

Dr. S. Høie, National Veterinary Institute, Norway

Dr. S. D. Miller, Institute of Aquaculture, University of Stirling, Scotland

Dr. T. P. T. Evelyn, Pacific Biological Station, Canada

Dr. T. Meyers, Department of Fish and Game, USA

Dr. T. Wiklund, Institute of Parasitology, Abo Akademi University, Finland

Dr. B. K. Guðmundsdóttir, Institute for Experimental Pathology, University of Iceland

Mr. L D. Ashburner, Department of Conservation Forests and Lands, Australia

Mrs. J. Petrie, Fisheries Research Services, Scotland

National Collection of Industrial and Marine Bacteria (NCIMB), Scotland

Prof. B. Austin, Heriot Watt University, Scotland

Prof. T. Aoki, Tokyo University of Fisheries, Japan 
Table 2. Non-target bacterial isolates employed as specificity controls during this study. NCFB: National Collection of Food Bacteria; other abbreviations in Table 1

\begin{tabular}{|c|c|}
\hline Bacterial species & Isolate number \\
\hline Yersinia ruckeri & ATCC 29473 \\
\hline Carnobacterium piscicola & ATCC 35586 \\
\hline Edwardsiella ictaluri & $85: 10067-1 \mathrm{~A}$ \\
\hline Lactococcus garvieae & ATCC 49156 \\
\hline Aeromonas hydrophila subsp. hydrophila & ATCC 7966 \\
\hline Aeromonas caviae & ATCC 15468 \\
\hline Aeromonas media & ATCC 33907 \\
\hline Aeromonas eucrenophila & ATCC 23309 \\
\hline Aeromonas veronii biovar veronii & ATCC 35624 \\
\hline Aeromonas veronii & ATCC 35941 \\
\hline Aeromonas schubertii & ATCC 43700 \\
\hline Aeromonas enteropelogenes & ATCC 49657 \\
\hline Aeromonas sobria & ATCC 43979 \\
\hline Aeromonas veronii biovar sobria & ATCC 9071 \\
\hline Aeromonas jandaei & ATCC 49568 \\
\hline Flexibacter maritimus & NCIMB 2154 \\
\hline Flexibacter ovolyticus & NCIMB 13127 \\
\hline Photobacterium phosphoreum & NCIMB 1282 \\
\hline Vibrio ordalii & NCIMB 2167 \\
\hline Vibrio tubiashii & NCIMB 1340 \\
\hline Vibrio anguillarum & ATCC 19264 \\
\hline Vagococcus salmoninarum & NCFB 2777 \\
\hline Vibrio alginolyticus & ATCC 17749 \\
\hline Vibrio harveyi & ATCC 14126 \\
\hline Vibrio vulnificus & ATCC 27562 \\
\hline Vibrio fluvialis & ATCC 33809 \\
\hline Vibrio natriegens & ATCC 14048 \\
\hline
\end{tabular}

Genomic DNA from an Aeromonas salmonicida isolate, demonstrated to be positive by the 3 PCRs, was used as a positive control; sterile distilled water served as the negative control. A PCR was deemed positive based on product size, as determined by agarose gel electrophoresis and as compared to known standards. If a particular sample yielded a negative result, it was subsequently re-tested as follows. If a sample was negative in all 3 systems, it was tested with universal primers specific for the $16 \mathrm{~S}$ ribosomal RNA gene. A negative result in this system indicated that amplification had been inhibited, and therefore the source bacterium was re-cultured, and the DNA isolated and retested. Each of the PCRs was optimised for use in our laboratory. Where reaction conditions used varied from those in previous publications they are indicated below.

Amplification with 16S rDNA primers (Dorsch \& Stackebrandt 1992): Each $25 \mu \mathrm{l}$ reaction contained $0.5 \mathrm{U}$ of DNA polymerase, $2.5 \mu \mathrm{l}$ of $10 \times$ PCR buffer, $1.5 \mathrm{mM} \mathrm{MgCl}_{2}, 9$ pmol each of the amplification primers 27f (5'-GAGTTTGATCCTGGCTCAG-3') and 1492r (5'-TACGGYTACCTTGTTACGACTT-3'), and all 4 deoxynucleotide triphosphates at $0.2 \mathrm{mM}$ each. Reaction mixes were held for 2 min at $94^{\circ} \mathrm{C}$, then amplified for 28 cycles, with denaturation for $30 \mathrm{~s}$ at $94^{\circ} \mathrm{C}$, annealing for $30 \mathrm{~s}$ at $49^{\circ} \mathrm{C}$ and elongation for $1 \mathrm{~min} 15 \mathrm{~s}$ at $72^{\circ} \mathrm{C}$. A final extension was performed at $72^{\circ} \mathrm{C}$ for $3 \mathrm{~min}$. The expected PCR product size was 1465 base pairs (bp).

Amplification with the PAAS primers (O'Brien et al. 1994): Each $25 \mu$ reaction contained $0.25 \mathrm{U}$ of DNA polymerase, $2.5 \mu$ of $10 \times$ PCR buffer, $2.5 \mathrm{mM} \mathrm{MgCl}_{2}$, 8 pmol each of the amplification primers PAAS1 CGTTGGATATGGCTCTTCCT-3') and PAAS2 (5'CTCAAAACGGCTGCGTACCA-3'), and all 4 deoxynucleotide triphosphates at $0.2 \mathrm{mM}$ each. Reaction mixes were held for $30 \mathrm{~s}$ at $95^{\circ} \mathrm{C}$, then amplified for 30 cycles, with denaturation for 2 min at $94^{\circ} \mathrm{C}$, annealing for $30 \mathrm{~s}$ at $57^{\circ} \mathrm{C}$ and elongation for $1 \mathrm{~min} 30 \mathrm{~s}$ at $72^{\circ} \mathrm{C}$. A final extension was performed at $72^{\circ} \mathrm{C}$ for $3 \mathrm{~min}$. The expected PCR product size was $423 \mathrm{bp}$.

Amplification with the AP primers (Gustafson et al. 1992): Each $25 \mu$ l reaction contained $0.25 \mathrm{U}$ of DNA polymerase, $2.5 \mathrm{\mu l}$ of $10 \times \mathrm{PCR}$ buffer, $2.5 \mathrm{mM} \mathrm{MgCl}_{2}$, 8 pmol each of the amplification primers AP1 (5'GGCTGATCTCTTCATCCTCACCC-3') and AP2 (5'CAGAGTGAAATCTACCAGCGGTGC-3'), and all 4 deoxynucleotide triphosphates at $0.2 \mathrm{mM}$ each. Reaction mixes were held for $2 \mathrm{~min}$ at $94^{\circ} \mathrm{C}$, then amplified for 30 cycles, with denaturation for $15 \mathrm{~s}$ at $94^{\circ} \mathrm{C}$, annealing for $30 \mathrm{~s}$ at $57^{\circ} \mathrm{C}$ and elongation for $1 \mathrm{~min} 30 \mathrm{~s}$ at $72^{\circ} \mathrm{C}$. A final extension was performed at $72^{\circ} \mathrm{C}$ for $3 \mathrm{~min}$. The expected PCR product size was $421 \mathrm{bp}$.

Amplification with the MIY primers (Miyata et al. 1996): Each $25 \mu$ reaction contained $0.6 \mathrm{U}$ of DNA polymerase, $2.5 \mu$ l of $10 \times$ PCR buffer, $1.5 \mathrm{mM} \mathrm{MgCl}_{2}$, 16 pmol each of the amplification primers MIY1 (5'AGCCTCCACGCGCTCACAGC-3') and MIY2 (5'AAGAGGCCCCATAGTGTGGG-3'), and all 4 deoxynucleotide triphosphates at $0.2 \mathrm{mM}$ each. Reaction mixes were held for $2 \mathrm{~min}$ at $94^{\circ} \mathrm{C}$, then amplified for 35 cycles, with denaturation for $30 \mathrm{~s}$ at $94^{\circ} \mathrm{C}$, and annealing and elongation for $1 \mathrm{~min} 30 \mathrm{~s}$ at $68^{\circ} \mathrm{C}$. A final extension was performed at $68^{\circ} \mathrm{C}$ for $3 \mathrm{~min}$. The expected PCR product size was $512 \mathrm{bp}$.

In vitro $\mathrm{PCR}$ specificity and sensitivity assays. The specificity of the PCR assays was determined by screening genomic DNA prepared from non-Aeromonas salmonicida isolates (Table 2) with the AP, PAAS and MIY PCRs. The sensitivity (i.e. the proportion of true negative results; see discussion) of the AP, PAAS and MIY assays was determined by PCR screening of the AFDL collection of A. salmonicida isolates ( $\mathrm{n}=308$ ). Each A. salmonicida genomic DNA sample was screened 4 times by each PCR.

Screening of Aeromonas salmonicida plasmids with the PAAS3 probe. Plasmids were extracted from selected $A$. salmonicida isolates using the BRESAspin $^{\mathrm{TM}}$ Plasmid Mini Kit (GeneWorks). The extracts 
were denatured by boiling for $10 \mathrm{~min}$, then blotted onto nylon membranes (Boehringer Mannheim) using the method of Reed \& Mann (1985). The PAAS3 probe (5'-GCTAGCCAACTCTCTTTCCA-3', O'Brien et al. 1994) was labelled with digoxygenin-11-dideoxyuridine triphosphate (ddUTP) (Boehringer Mannheim) and terminal deoxynucleotidyl transferase (Boehringer Mannheim). Pre-hybridisation was performed for $1 \mathrm{~h}$ at $10^{\circ} \mathrm{C}$ below the probe's theoretical maximum temperature $\left(T_{\mathrm{m}}\right)$ of $60^{\circ} \mathrm{C}$. Hybridisation and detection of the digoxigenin-labelled oligonucleotide were performed by using alkaline phosphatase-labelled anti-digoxigenin Fab antibody fragments (Boehringer Mannheim) and the chemiluminescent alkaline phosphatase substrate CDP-Star ${ }^{\mathrm{TM}}$ (Boehringer Mannheim) according to the manufacturer's recommended procedure.

Sodium dodecyl sulphate-polyacrylamide gel electrophoresis (SDS-PAGE) and western blotting. Preparation of samples: Aeromonas salmonicida isolates were cultured on $5 \%$ SBA for $48 \mathrm{~h}$ at $25^{\circ} \mathrm{C}$ in air, harvested and washed 3 times in sterile phosphate buffered saline without $\mathrm{Ca}^{2+}$ and $\mathrm{Mg}^{2+}$ ions (PBSA, $\mathrm{pH}$ 7.4), and approximately $100 \mathrm{mg}$ of bacteria were sedimented at $13000 \times g$ for $1 \mathrm{~min}$. The pellet was resuspended in $1 \mathrm{ml}$ SDS-glycerol buffer (10\% glycerol, $2.3 \%$ SDS, $0.0625 \mathrm{M}$ Tris/HCl pH 6.8, 5\% mercaptoethanol) and incubated at $100^{\circ} \mathrm{C}$ for $10 \mathrm{~min}$, and insoluble material was removed by centrifugation at $13000 \times g$ for $5 \mathrm{~min}$. The supernatant was frozen at $-20^{\circ} \mathrm{C}$ prior to electrophoresis.

Electrophoresis: Bacterial proteins were analysed by western blotting following electrophoresis using the buffer system of Laemmli (1970). Bacterial proteins were resolved in $0.75 \mathrm{~mm} \times 8 \mathrm{~cm} 12 \%$ (w/v) acrylamide gels overlayed with a $2.5 \mathrm{~cm} 4.75 \%$ (w/v) stacking gel. Piperazine diacrylamide was substituted for $\mathrm{N}, \mathrm{N}^{\prime}$-methylene-bis-acrylamide on a weight for weight basis, the final concentration of cross-linker being $2.67 \%(\mathrm{w} / \mathrm{v})$ with respect to total acrylamide. Gels were run at $10 \mathrm{~mA}$ for $10 \mathrm{~min}$ followed by $50 \mathrm{~mA}$ constant current until the dye front reached the bottom of the resolving gel. For electrophoresis, approximately 5 to $20 \mu \mathrm{l}$ of sample was loaded in each well, the respective volumes having been previously estimated to give equal staining intensity in each lane.

Western blotting: Following electrophoresis, proteins were transferred to $0.22 \mu \mathrm{m}$ nitrocellulose sheets (NitroPure, Micron Separations, \#WP2HY00010) at $30 \mathrm{~V}$ for $16 \mathrm{~h}$ at $4^{\circ} \mathrm{C}$ using the buffer system of Towbin et al. (1979). The transferred bacterial proteins were probed with hyper-immune polyclonal antisera raised against Aeromonas salmonicida A-protein (supplied by Dr. Guri Eggset, Marin Bioteknologi i Tromsø, Norway) using methods described previously (Crane et al. 2000).
DNA sequencing. Products (typically $50 \mathrm{ng}$ DNA) from the 16S PCRs were sequenced with the ABI Prism $^{\circledR}$ BigDye $^{\text {TM }}$ Terminator Cycle Sequencing Ready Reaction Kit (PE Applied Biosystems) using the 1110f primer (5'-GCAACGAGCGCAACCC-3'; Dorsch \& Stackebrandt 1992), purified using the QIAquick PCR Purification Kit (Qiagen), and run on an ABI model 377 automated sequencer (PE Applied Biosystems). The resultant sequences were compared against the GenBank database using the basic local alignment search tool (BLAST; Altschul et al. 1990) to determine their general taxonomic affiliation.

Preparation of bacterial inocula for seeded tissue studies. Aeromonas salmonicida isolate SFC 262 (biochemical profile shown in Table 3) was chosen for seeding experiments as it was positive by the AP, PAAS and MIY PCRs, and had been subject to minimal passage. An overnight culture grown on SBA at room temperature was used to prepare a cell suspension of 115 nephalometric turbidity units (NTUs) in $15 \mathrm{ml}$ sterile PBSA as determined by the Hach nephalometer. The number of cells present in the suspension was calculated by either drop plate counts (Miles \& Misra 1938) or direct counts using the WSI Counting Chamber (Weber Scientific International). Aliquots of dilutions of the suspension ranging from $10^{8}$ colony-forming units (CFU) $\mathrm{ml}^{-1}$ to $10^{4} \mathrm{CFU} \mathrm{ml} \mathrm{l}^{-1}$ were added to the tissue samples.

Preparation of fish tissues for seeded tissue studies. Mucus, gill, spleen, kidney and intestine samples were obtained from uninfected rainbow trout Oncorhynchus mykiss and brown trout Salmo trutta for use in seeding experiments. Mucus was diluted 1:1 (w/v) with

Table 3. Summary of the biochemical profile of Aeromonas salmonicida isolate SFC 262. TSA: tryptic soy agar; SBA: sheep blood agar: +: positive; -: negative

\begin{tabular}{|lc|}
\hline Test & Result \\
\hline Gram stain & - \\
Pigment production on TSA & + \\
Cytochrome oxidase & + \\
Motility & - \\
Growth on SBA at $37^{\circ} \mathrm{C}$ & - \\
Indole & - \\
Methyl red & + \\
Voges-Proskauer & - \\
Arginine dihydrolase & + \\
Nitrate reduction & + \\
Aesculin hydrolysis & + \\
Gas production from D-glucose & + \\
Acid from arabinose & + \\
Acid from galactose & + \\
Acid from maltose & + \\
Acid from mannitol & + \\
Acid from sucrose & + \\
Acid from trehalose & - \\
\hline
\end{tabular}


sterile PBSA, mixed thoroughly, and divided into $100 \mu \mathrm{l}$ aliquots. Tissues were divided into $50 \mathrm{mg}$ aliquots. All aliquots were stored at $-20^{\circ} \mathrm{C}$ prior to use.

Extracting DNA from seeded and unseeded salmonid tissues. Unless otherwise stated, seeded tissue samples consisted of $50 \mu \mathrm{l}$ of Aeromonas salmonicida cell suspension and 1 aliquot of frozen fish tissue (prepared as above) added to $200 \mu \mathrm{l}$ of sterile distilled water in a $1.5 \mathrm{ml}$ Eppendorf tube, then macerated with a Kontes Pellet Pestle ${ }^{\circledR}$ (Edwards Scientific), vortexed and processed as outlined below. Unseeded samples were processed in the same manner and contained fish tissue but no A. salmonicida cells. Extraction methods (boiling with or without Chelex-100 resin; BioRad ${ }^{\circledR}$ Biotechnology Grade, Sodium Form), Triton X-100 methods (Agersborg et al. 1997, Khan \& Cerniglia 1997), enzymatic/chemical lysis method (Sambrook et al. 1989) and Puregene ${ }^{\circledR}$ Kit (Gentra Systems) were trialled. The method of choice, based on nucleic acid yield and purity, was the Puregene ${ }^{\circledR}$ Kit, which was used as per manufacturer's instructions, except that all reagent volumes were doubled and extracts were diluted 1:20 in sterile distilled water prior to PCR.

Calculation of the lower detection limit (LDL) of the PCRs based on purified DNA preparations. Genomic DNA was extracted from Aeromonas salmonicida using the Puregene ${ }^{\circledR}$ Kit and quantified using the GeneQuant II RNA/DNA calculator (Pharmacia Biotech). Serial dilutions of the DNA, ranging from $20 \mathrm{ng}$ to $20 \mathrm{fg}$, were used as template directly in the AP, PAAS and MIY PCR assays. Alternatively, the $A$. salmonicida DNA was mixed with 1 to $2 \mu \mathrm{g}$ aliquots of brown trout tissue DNA (extracted from $50 \mathrm{mg}$ of either mucus, kidney, spleen, intestine or gill material using the Puregene ${ }^{\circledR}$ Kit), and then amplified in the AP, PAAS and MIY PCRs, in order to determine the effect of high levels of non-target DNA on the performance of the PCRs.

Calculation of the LDL of the PCRs based on addition of Aeromonas salmonicida whole cell preparations. Whole cell suspensions of $A$. salmonicida were prepared as above, and $50 \mu$ laliquots of cells suspensions ranging from $10^{7}$ to $10^{3} \mathrm{CFU} \mathrm{ml}{ }^{-1}$ were added to $50 \mathrm{mg}$ lots of fish tissues. DNA was extracted using the Puregene ${ }^{\circledR}$ Kit and amplified using the AP, PAAS and MIY PCRs.

Aeromonas salmonicida overt infection in fish held at AFDL. All fish infection experiments were conducted at $18^{\circ} \mathrm{C}$. Brown trout Salmo trutta were anaesthetised with benzocaine $\left(10 \mathrm{mg} \mathrm{l}^{-1}\right)$ and inoculated with $10^{4}$ to $10^{6}$ cells of $A$. salmonicida (SFC 262) in $100 \mu \mathrm{l}$ of sterile saline by injection into the abdominal cavity. Fish were then transferred to separate 701 aquaria and monitored daily for clinical signs of disease such as gross lesions, lethargy and abnormal swimming behaviour. Fish displaying any signs were euthanised by benzocaine overdose (100 $\left.\mathrm{mg} \mathrm{l}^{-1}\right)$. Uninfected control fish $(\mathrm{n}=10)$, injected intraperitoneally (i.p.) with $100 \mu \mathrm{l}$ sterile saline only, were maintained under the same conditions. Ten days after the initial exposure, surviving fish were euthanised by anaesthetic overdose and sampled.

Identification of Aeromonas salmonicida from experimentally infected fish tissue. Samples of mucus, gill, kidney, spleen and intestine from the brown trout were inoculated onto SBA plates and incubated for $48 \mathrm{~h}$ at $20^{\circ} \mathrm{C}$. Colonies suspected to be A. salmonicida were either used directly as template in the PCR mix or subcultured and DNA extracted using the Puregene ${ }^{\circledR}$ Kit to provide a source of template for the AP, PAAS and MIY PCRs. Alternatively, the Puregene ${ }^{\circledR}$ Kit was used to directly extract DNA from $50 \mathrm{mg}$ aliquots of fish tissue, which had been aseptically excised from the necropsied fish. This DNA was then used as template in the AP, PAAS and MIY PCR assays.

\section{RESULTS}

\section{Biochemical characterisation of Aeromonas salmonicida isolates}

A total of 243 Aeromonas salmonicida isolates from the AFDL reference collection were characterised using a panel of 18 phenotypic tests. Results from 14 of the biochemical tests were forwarded to Prof. Brian Austin (Department of Biological Sciences, HeriotWatt University, Edinburgh) for computer-assisted cluster analysis. Results from this analysis grouped the isolates into 30 phenotypic clusters (data not shown), reflecting the broad phenotypic diversity of the species. Hence, on the basis of phenotypic testing alone it was not possible to accurately assign all the isolates to a recognised subspecies.

\section{In vitro specificity and sensitivity of PAAS and AP PCR tests}

The PAAS (Hiney et al. 1992) and AP (Gustafson et al. 1992) PCR tests did not produce any false positive reactions with the 27 non-target bacterial DNA extracts and, on this basis, were considered to be specific for their target, Aeromonas salmonicida.

The AP PCR correctly identified 288 of the 308 isolates as Aeromonas salmonicida and was therefore determined to have an in vitro sensitivity of $93.3 \%$. The PAAS PCR correctly identified 285 of the 308 isolates as A. salmonicida and was therefore determined to have an in vitro sensitivity of $93 \%$. When the results 
of both tests were combined, $99.4 \%$ of the isolates in the library were correctly identified as A. salmonicida. The $0.6 \%$ false negative isolates were further examined in order to determine the reason(s) for these results.

As the primer binding sites for the PAAS PCR are plasmid borne, plasmid DNA was isolated from PAAS PCR-negative isolates (Fig. 1) and probed with the PAAS3 probe in order to determine whether the target primer site was present. The PAAS3 probe hybridised with a band, approximately $6 \mathrm{~kb}$ in size, in the plasmid profiles of the positive controls SFCs 190 and 308 (as indicated by the arrow in Fig. 1), indicating that the plasmid target site was present in these 2 isolates. Failure of the PAAS3 probe to hybridise with the remaining plasmid extracts indicated that the isolates SFC 20,21, 22, 123, $164,168,170,187,188,191,192,197,198,213$, $222,226,229,259,480,484,491,725$ and 728 may lack the target plasmid.

Further studies using the western blotting technique with the A-protein-specific antiserum were undertaken in order to determine whether the vapA gene, which contains the AP PCR primer sites, was functional and being expressed. It was demonstrated that AP PCR-positive isolates did not necessarily express the A-protein, e.g. Aeromonas salmonicida American Type Culture Collection (ATCC) 14172 (SFC 36). It was also demonstrated that some AP PCR-negative isolates could continue to produce the A-protein, e.g. SFCs 308, 317, 481, 483 and 484 (Fig. 2).

\section{In vitro sensitivity and specificity of the MIY PCR test}

The MIY PCR correctly identified all isolates from the AFDL collection previously identified as Aeromonas salmonicida subsp. salmonicida, including all isolates submitted as 'typical' and presumed to be A. salmonicida subsp. salmonicida, and 85 of the 128 isolates that were submitted with no description but were found to be indole negative. Isolates that are negative for indole production are usually, but not always, A. salmonicida subsp. salmonicida. The test did not yield false positive results with any of the negative control extracts, any other A. salmonicida subspecies or any isolates from the collection that were considered to be 'atypical'.

\section{S rDNA sequencing}

The 2 Aeromonas salmonicida isolates that were negative by all 3 PCR tests were subjected to partial $16 \mathrm{~S}$ rDNA sequencing to confirm their identity. The $16 \mathrm{~S}$

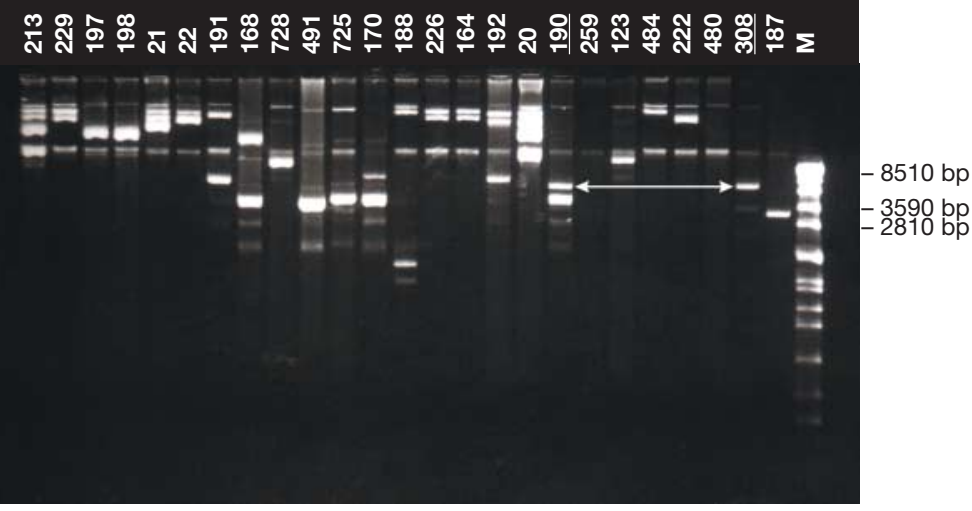

Fig. 1. Aeromonas salmonicida. Plasmids extracted from the previously PAAS PCR-negative A. salmonicida isolates using the BRESAspin ${ }^{\mathrm{TM}}$ Plasmid Mini Kit (GeneWorks). A. salmonicida SFC isolate numbers are marked above their corresponding plasmid profiles. The rrow indicates the plasmids of the 2 isolates (underlined) that hybridised with the PAAS3 probe. M: molecular weight marker SPP-1 DNA/ECoR1

rRNA genes were amplified and partially sequenced using the 1100f primer (Dorsch \& Stackebrandt 1992). The general taxonomic affiliation and likely source of the sequences, as determined using the BLAST tool available on ANGIS (Australian National Genomic Information Service), was A. salmonicida.

\section{Extracting DNA from seeded and unseeded salmonid tissues}

The enzymatic/chemical lysis method and the Puregene ${ }^{\circledR}$ Kit yielded better quality DNA and led to the best LDL compared to the boiling, Proteinase K, Triton X-100, Chelex or Chelex and Triton methods (Byers et

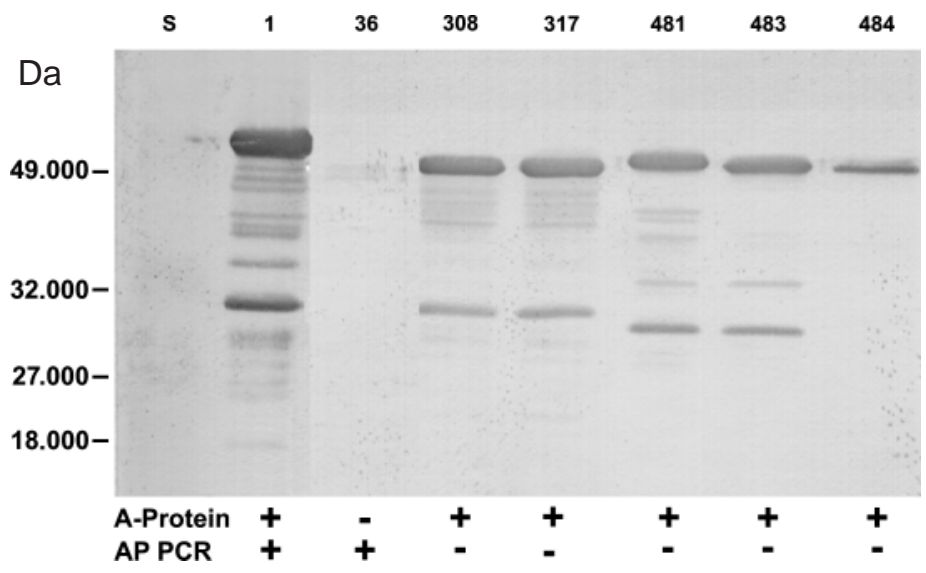

Fig. 2. Aeromonas salmonicida. Western blotting of protein profiles of selected isolates. Results with isolates 1, 36, 308, 317, 481, 483 and 484 demonstrate that there is no direct correlation between the presence of A-protein and the AP PCR result. Lane S contains the protein molecular weight standards 
al. 2000). As the Puregene ${ }^{\circledR}$ Kit was simpler and faster to use, it became the method of choice for all future DNA extractions.

\section{Determination of the LDL of the PCRs}

The LDL of the PCRs were determined for DNA extracts and for whole cell seeded preparations. The addition of $1 \mu \mathrm{g}$ of non-target fish tissue DNA to Aeromonas salmonicida DNA in the PCR mix led to a decrease in the LDL of the PCRs by about 1 order of magnitude (Table 4). When cocktails of low amounts of target DNA $(<20 \mathrm{pg})$ and high levels of non-target DNA ( 1 to $2 \mu \mathrm{g}$ ) were tested with the PAAS PCR, some non-specific products were found to occur (example given in Fig. 3). However, these extraneous bands were of a different size from the desired product, and in these cases the target band could be excised from the gel and sequenced to confirm identity.

\section{Culture-based identification of Aeromonas salmonicida in experimentally infected fish}

Bacteria were readily isolated on SBA from the mucus, gills, intestine, kidney and spleen of 20 dead fish. Isolates were positive by the AP, PAAS and MIY PCRs (results not shown). Amplifying directly from the bacterial colony (i.e. aseptically transferring a small amount of isolate to the PCR mix itself) was successful $90 \%(\mathrm{n}=100)$ of the time. Extracting DNA from the isolate with the Puregene ${ }^{\circledR}$ Kit prior to PCR ensured a $100 \%$ success rate.

\section{Direct PCR detection of Aeromonas salmonicida in experimentally infected fish}

The AP and PAAS PCR assays successfully detected the presence of $A$. salmonicida in mucus, gill, muscle lesion, intestine, spleen and kidney samples obtained from each of 20 experimentally infected fish. The

Table 4. Lower detection limits (LDLs) of the Aeromonas salmonicida PCRs. CFU: colony-forming units

\begin{tabular}{|c|c|c|c|}
\hline \multirow[t]{2}{*}{ PCR } & \multicolumn{3}{|c|}{ Range of LDL of PCRs } \\
\hline & $\begin{array}{c}\text { Target template } \\
\text { only, } \\
\text { per } 50 \mu \mathrm{l} \text { PCR }\end{array}$ & $\begin{array}{c}\text { Target template }+ \\
1 \mu \mathrm{g} \text { fish tissue DNA, } \\
\text { per } 50 \mu \mathrm{l} \text { PCR }\end{array}$ & $\begin{array}{c}\mathrm{CFU} \mathrm{g}^{-1} \\
\text { tissue }\end{array}$ \\
\hline PAAS & $2 \mathrm{pg}$ to $200 \mathrm{fg}$ & $20 \mathrm{pg}$ to $2 \mathrm{pg}$ & $10^{4}$ to $10^{3}$ \\
\hline AP & $20 \mathrm{pg}$ to $2 \mathrm{pg}$ & $200 \mathrm{pg}$ to $20 \mathrm{pg}$ & $10^{5}$ to $10^{4}$ \\
\hline MIY & $20 \mathrm{ng}$ to $2 \mathrm{ng}$ & $200 \mathrm{ng}$ to $20 \mathrm{ng}$ & $10^{7}$ to $10^{6}$ \\
\hline
\end{tabular}

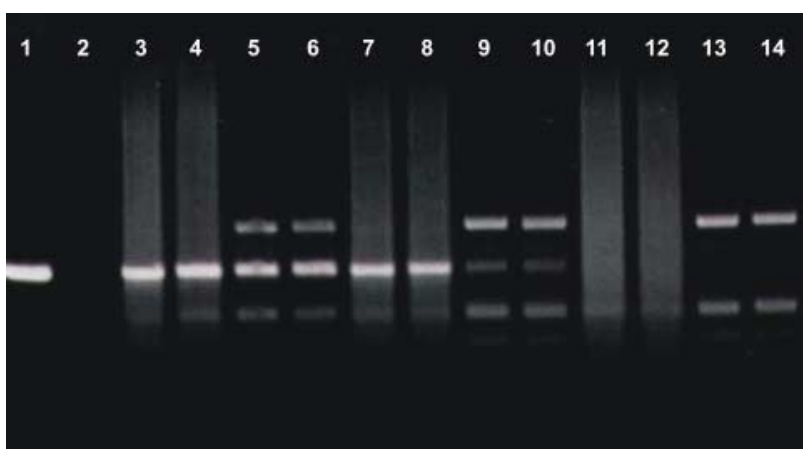

Fig. 3. PAAS PCR of kidney tissue seeded with whole cell preparations of Aeromonas salmonicida. Lane 1 is the positive PCR control (template was $200 \mathrm{pg}$ A. salmonicida DNA and the PCR product is $423 \mathrm{bp}$ ) and lane 2 is the negative control (no A. salmonicida DNA added to the PCR). The templates used in lanes $3-4,7-8$ and 11-12 were extracts prepared from $25 \mathrm{mg}$ brown trout kidney tissue seeded with $2 \times 10^{3}$ $2 \times 10^{2}$ and $2 \times 10^{1} \mathrm{~A}$. salmonicida colony-forming units (CFU), respectively. The templates used in lanes 5-6, 9-10 and 13-14 were amplified from 1:20 dilutions of extracts prepared from $50 \mathrm{mg}$ brown trout kidney tissue seeded with $2 \times 10^{3}$, $2 \times 10^{2}$ and $2 \times 10^{1} \mathrm{~A}$. salmonicida CFU, respectively

MIY PCR was not routinely used to screen the tissue extracts due to its poorer LDL.

In addition, it was found that using Platinum ${ }^{\mathrm{TM}}$ Taq (Life Technologies ${ }^{\mathrm{TM}}$ ), as opposed to Taq DNA polymerase (Promega Corporation), significantly improved the performance of all 3 PCR systems (example given in Fig. 4) and so became the DNA polymerase of choice.

\section{DISCUSSION}

An extremely broad phenotypic diversity was expressed by the Aeromonas salmonicida isolates, with 30 separate clusters being recognised (data not shown).

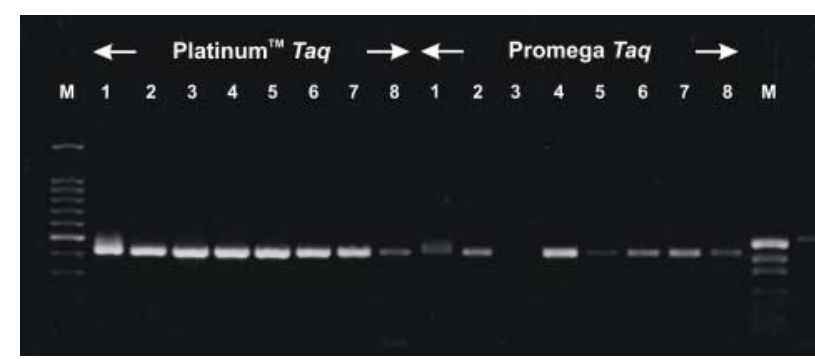

Fig. 4. PAAS PCR of extracts prepared from experimentally infected brown trout kidney tissue. Two different DNA polymerases (Platinum ${ }^{\mathrm{TM}}$ Taq and Promega Taq) were used with various DNA extraction methods: lanes 1-2, boiling method; lanes 3-4, Puregene ${ }^{\circledR}$ Kit; lanes 5-6, enzymatic/chemical lysis method; and lanes 7-8, Chelex/Triton method. Lanes M: molecular weight markers Promega 100 bp ladder (No. G210A) and pUC19/HpaII, respectively 
It was observed that the phenotypic tests employed in this study were often inadequate with regard to the accurate identification of $A$. salmonicida isolates to both species and subspecies levels. For example, 3 isolates were negative by the cytochrome oxidase test. Such results should have excluded these isolates from the species A. salmonicida, yet other tests including $\mathrm{PCR}$ and sequencing indicated that these isolates were indeed A. salmonicida. This and other, previous reports in the literature of such anomalies within this species (Chapman et al. 1991, McIntosh \& Austin 1991, Teska et al. 1992, Wiklund et al. 1994, Pedersen et al. 1996) highlight the need for improved diagnostic techniques for the identification of $A$. salmonicida.

As diagnosis of Aeromonas salmonicida in Australia would have far-reaching consequences, it was vital that the candidate PCRs examined in this study be systematically evaluated. It is important to remember that non-culture-based methods such as PCR, enzymelinked immunosorbent assay (ELISA) and western blotting provide us with an indication or sign that the target organism is present, as opposed to isolating the viable disease-causing agent itself. Hence, they are referred to as 'proxy' methods or measurements because they only indirectly indicate the presence of the target organism in a sample (Hiney 1997). Therefore, the application of such proxy measurements must be validated, i.e. the extent to which the technique can be legitimately used for a specified purpose must be thoroughly investigated (Hiney \& Smith 1998).

The first stage of developing the diagnostic procedures involved using the candidate PCRs to screen the bacterial isolates in AFDL's reference collection. The key issues to be considered here are specificity, i.e. the proportion of true positive results, and sensitivity, i.e. the proportion of true negative results (Bernoth 1997). The putative Aeromonas salmonicida-specific PCR tests appeared to be $100 \%$ specific and did not cross-react with any of the non-target organisms tested. It was found that combining the results of both the AP and PAAS tests offered the best 'coverage' in terms of identifying the target organism, with only $0.6 \%$ of 308 A. salmonicida isolates being falsely recorded as negative. To date the MIY PCR appears to be $100 \%$ specific for A. salmonicida subsp. salmonicida, thus allowing us to distinguish between typical and atypical A. salmonicida isolates.

The failure of the PAAS primer set to identify $100 \%$ of the Aeromonas salmonicida isolates appeared to be related to the primer target site, which had previously been shown to occur on a $6.4 \mathrm{~kb}$ cryptic plasmid (Mooney et al. 1995) and was believed to be present in approximately $90 \%$ of $A$. salmonicida isolates (R. Powell pers. comm.). The plasmid profiles of those isolates found to be PAAS PCR-negative were probed with the
PAAS3 nucleic acid probe (O'Brien et al. 1994), indicating that the primer target site may be absent in these 23 isolates. Extracts of 2 PAAS PCR-positive isolates were included and demonstrated to contain a fragment, approximately $6 \mathrm{~kb}$ in size (Fig. 1) that did hybridise with the PAAS probe.

The failure of the AP primer set to identify all of the Aeromonas salmonicida isolates is related to its primer target site, the vapA gene, which encodes a unique subunit protein (the 'A-protein') of the A-layer of $A$. salmonicida (Chu et al. 1991). As previously observed by Gustafson et al. (1992), it was demonstrated that AP PCR-positive isolates did not necessarily express the A-protein, e.g. SFC 36 (Fig. 2). In addition, it was demonstrated that some of the AP PCR-negative isolates were still able to express A-protein, e.g. SFC 308 (Fig. 2), which may be due to a mutation within the priming site, but still leaves the gene functional.

Once the PCR tests had been validated using a large number of purified Aeromonas salmonicida DNA preparations, seeded tissue studies were undertaken. Most available data regarding the trialling of PCRs to detect infectious material involves the use of seeded tissue, i.e. healthy tissue that is 'spiked' with a known pathogen. It should be remembered that there are numerous fundamental differences between infected tissues that harbour a pathogen and healthy tissue seeded with a laboratory-grown bacterium. For example, the expressed phenotype of the bacterium may differ (Fernandez et al. 1995, Garduno \& Kay 1995), the physical and chemical accessibility of the pathogen may be quite different, and additional PCR inhibitors could be present in the infected tissue. However, bearing these constraints in mind, experiments involving seeded tissue proved to be a useful starting point permitting optimisation of experimental diagnostic procedures and the empirical determination of the LDLs of the PCRs.

Addition of either fish tissue or fish tissue DNA to the PCR mix was found to have an inhibitory effect on all of the PCRs. This type of interference has been reported previously (e.g. Gustafson et al. 1992, Høie et al. 1997) and is a major limitation of the direct PCR detection of a target pathogen in infected tissue samples. It was also noted that weak non-specific products occurred in the PCRs when high levels of non-target DNA ( $>1 \mu \mathrm{g})$ were included in the reaction mix. This result may be due to large concentrations of non-target DNA 'out-competing' the target DNA (which has higher homology with the primers, but occurs much less frequently) with regard to primer binding sites, particularly in the first few rounds of amplification. However, these non-specific products were not deemed to be a problem as they differ in size from the desired product. Also, since typical Aeromonas sal- 
monicida is exotic to Australia, sequencing the PCR product would be part of the diagnostic procedure to confirm the identity of the product.

The PAAS PCR had the lowest detection limit with regard to purified target template only, being in the range $2 \mathrm{pg}$ to $200 \mathrm{fg}$ per PCR. Hiney et al. (1992) reported a PAAS detection limit of $10 \mathrm{fg}$ DNA, but this was achieved using a $\mathrm{MgCl}_{2}$ concentration of $3.5 \mathrm{mM}$ (compared to the more stringent $2.5 \mathrm{mM} \mathrm{MgCl}_{2}$ concentration used in this study in order to maximise the specificity of the PCR) and a radioactively labelled probe to detect the PCR products. O'Brien et al. (1994) also reported a LDL of 200 genome equivalents (GE) $\mathrm{g}^{-1}$ sample using the PAAS PCR, which is equivalent to 1 pg target DNA $\mathrm{g}^{-1}$ sample based on the assumption that $1 \mathrm{GE}$ is approximately $5 \mathrm{fg}$ (Gustafson et al. 1992). It must be realised, however, that the study of O'Brien et al. (1994) involved either filtered effluent or faecal matter, both of which may differ in the level of inhibition they have on the PCR compared to fish tissue. More important, their measurement of the LDL was based on a comparison of PCR yield with that obtained when using pure DNA as a template. Given the nonlinear kinetics of $\mathrm{PCR}$, such a comparison could be inaccurate and could account for the differences between the reported LDLs and the limits determined in this study. Mooney et al. (1995), using a nested PAAS PCR, reported a LDL of $100 \mathrm{GE}$ fish $^{-1}$. However, as Bernoth (1997) points out, the $100 \mathrm{GE}$ limit was in fact per 10 to $100 \mu \mathrm{l}$ of blood sample, and so actually equates to $10^{3}$ to $10^{4} \mathrm{GE} \mathrm{ml} l^{-1}$ blood, which is equivalent to the level determined in this study. It is therefore considered that the PAAS PCR LDLs calculated in this study are a realistic measure of the performance of the PCR, as applied to seeded tissue samples.

Gustafson et al. (1992) had reported a LDL of $10^{4} \mathrm{CFU} \mathrm{g}^{-1}$ when the AP PCR was applied to fish tissue samples seeded with known amounts of Aeromonas salmonicida, and our results fall within this limit. In fact, the LDLs of the AP and PAAS PCRs are approaching the theoretical limit of direct PCR detection, based on the figure of $2 \times 10^{3}$ cells $^{-1}$ fish tissue as calculated by Carson (1998). The only means of improving upon this figure is to concentrate the target DNA prior to PCR, perhaps via a cultural pre-enrichment step (Gustafson et al. 1992). Unfortunately, the MIY PCR was unable to reach the detection limits of the AP and PAAS PCRs.

It is important to note that these LDL values cannot be extrapolated to determine the performance of the PCRs in the case of infected tissues. Therefore, the PCR tests were further evaluated using tissues obtained from experimentally infected fish. The use of i.p. injection of Aeromonas salmonicida to generate experimental infection in fish is a highly reproducible procedure, but it does not mimic the process of natural infection. However, at least this procedure provided the target pathogen the opportunity to reproduce within the host, possibly allowing alterations of phenotype to occur. Thus, infection of fish provided a 'nonsterile incurred matrix' (Hiney 1997) in which the bacterium was embedded, as opposed to simply mixing healthy fish tissue and a laboratory-grown strain of A. salmonicida.

All 3 PCR tests successfully identified bacteria isolated on SBA from the mucus, gills, gut, kidney and spleen of the experimentally infected brown trout. Both the AP and PAAS PCRs yielded positive results when directly applied to overtly infected mucus, gill, intestine, muscle lesion, spleen and kidney samples. The MIY PCR, however, was less sensitive when used to screen tissue samples directly, and this PCR would require some form of pre-enrichment step to improve its performance.

Overall, the AP, PAAS and MIY PCRs appear to have a high level of specificity and sensitivity with regard to identifying pure bacterial cultures and have been incorporated into the suite of diagnostic tests used by this laboratory for the rapid identification and differentiation of isolates of Aeromonas salmonicida. Based on seeded tissue studies and experimental infection trials, the AP and PAAS PCRs were also demonstrated to have the potential to be used in the direct screening of fish tissue samples. However, the performance of these PCRs will still have to be validated using naturally infected fish if they are to be used routinely in the diagnosis of both overt and covert A. salmonicida infections.

Acknowledgements. The authors acknowledge support from the Fisheries Research and Development Corporation Project \#95/060.

\section{LITERATURE CITED}

Agersborg A, Dahl R, Martinez I (1997) Sample preparation and DNA extraction procedures for polymerase chain reaction identification of Listeria monocytogenes in seafoods. Int J Food Microbiol 35:275-280

Altschul SF, Gish W, Miller W, Meyers EW, Lipman DJ (1990) Basic local alignment search tool. J Mol Biol 215:403-410

Austin B, Austin DA (1999) Bacterial fish pathogens: disease in farmed and wild fish, 3rd edn. Springer-Praxis, Chichester

Austin B, Austin DA, Dalsgaard I, Gudmundsdottir BK and 5 others (1998) Characterization of atypical Aeromonas salmonicida by different methods. Syst Appl Microbiol 21:50-64

Balows E, Hausler WJ, Herrmann KL, Isenberg HD, Shadomy HJ (eds) (1993) Manual of clinical microbiology, 5th edn. American Society of Microbiology, Washington, DC

Bernoth EM (1997) Diagnosis of furunculosis: the tools. In: Bernoth EM, Ellis AE, Midtlyng PJ, Olivier G, Smith P 
(eds) Furunculosis: multidisciplinary fish disease research. Academic Press, London, p 98-158

Byers HK, Gudkovs N, Crane M (2000) Final report on FRDC project 95/060: diagnosis and identification of Aeromonas salmonicida and detection of latent infections in carrier fish. CSIRO Australian Animal Health Laboratory, Geelong

Carson J (1998) Final report on FRDC project 93/128: development of molecular probes for use in bacterial disease diagnosis and health monitoring of farmed and wild finfish in Australia. Department of Primary Industries and Fisheries, Launceston, Tasmania

Chapman PF, Cipriano RC, Teska JD (1991) Isolation and phenotypic characterization of an oxidase-negative Aeromonas salmonicida causing furunculosis in coho salmon (Oncorhynchus kisutch). J Wildl Dis 27:61-67

Chu S, Cavaignac S, Feutrier J, Phipps BM and 3 others (1991) Structure of the tetragonal surface virulence array protein and gene of Aeromonas salmonicida. J Biol Chem 266:15258-15265

Crane MStJ, Hardy-Smith P, Williams LM, Hyatt AD, Eaton LM and 4 others (2000) First isolation of an aquatic birnavirus from farmed and wild fish species in Australia. Dis Aquat Org 43:1-14

Dorsch M, Stackebrandt E (1992) Some modifications in the procedure of direct sequencing of PCR amplified 16S rDNA. J Microbiol Methods 16:271-279

Fernandez AI, Perez MJ, Rodriguez LA, Nieto TP (1995) Surface phenotypic characteristics and virulence of Spanish isolates of Aeromonas salmonicida after passage through fish. Appl Environ Microbiol 61:2010-2012

Garduno RA, Kay WW (1995) Capsulated cells of Aeromonas salmonicida grown in vitro have different functional properties than capsulated cells grown in vivo. Can J Microbiol 41:941-945

Gustafson CE, Thomas CJ, Trust TJ (1992) Detection of Aeromonas salmonicida from fish by using polymerase chain reaction amplification of the virulence surface array protein gene. Appl Environ Microbiol 58:3816-3825

Hiney M (1997) How to test a test: methods of field validation for nonculture-based detection techniques. Bull Eur Assoc Fish Pathol 17:245-250

Hiney M, Olivier G (1999) Furunculosis (Aeromonas salmonicida). In: Woo PTK, Bruno DW (eds) Fish diseases and disorders, Vol 3. Viral, bacterial and fungal infections. CABI Publishing, Oxon, p 341-425

Hiney MP, Smith PR (1998) Validation of polymerase chain reaction-based techniques for proxy detection of bacterial fish pathogens: framework, problems and possible solution for environmental applications. Aquaculture 162:41-68

Hiney M, Dawson MT, Heery DM, Smith PR, Gannon F, Powell R (1992) DNA probe for Aeromonas salmonicida. Appl Environ Microbiol 58:1039-1042

Hiney M, Smith P, Bernoth EM (1997) Covert Aeromonas salmonicida infections. In: Bernoth EM, Ellis AE, Midtlyng PJ, Olivier G, Smith P (eds) Furunculosis: multidisciplinary fish disease research. Academic Press, London, p 54-97

Høie S, Heum M, Thoresen OF (1997) Evaluation of a polymerase chain reaction-based assay for the detection of

Editorial responsibility: Carey Cunningham,

Aberdeen, Scotland, UK
Aeromonas salmonicida ss salmonicida in Atlantic salmon Salmo salar. Dis Aquat Org 30:27-35

Huys G, Swings J (1999) Evaluation of a fluorescent amplified fragment length polymorphism (FAFLP) methodology for the genotypic discrimination of Aeromonas taxa. FEMS Microbiol Lett 177:83-92

Khan AA, Cerniglia CE (1997) Rapid and sensitive method for the detection of Aeromonas caviae and Aeromonas trota by polymerase chain reaction. Lett Appl Microbiol 24: 233-239

Laemmli UK (1970) Cleavage of structural proteins during the assembly of the head of bacteriophage T4. Nature 227: 680-685

McIntosh D, Austin B (1991) Atypical characteristics of the salmonid pathogen Aeromonas salmonicida. J Gen Microbiol 137:1341-1343

Miles AA, Misra SS (1938) The estimation of the bactericidal power of the blood. J Hyg 38:732-749

Miyata M, Inglis V, Aoki T (1996) Rapid identification of Aeromonas salmonicida subspecies salmonicida by the polymerase chain reaction. Aquaculture 141:13-24

Mooney J, Powell E, Clabby C, Powell R (1995) Detection of Aeromonas salmonicida in wild Atlantic salmon using a specific DNA probe test. Dis Aquat Org 21:131-135

O'Brien D, Mooney J, Ryan D, Powell E, Hiney M, Smith PR, Powell R (1994) Detection of Aeromonas salmonicida, causal agent of furunculosis in salmonid fish, from the tank effluent of hatchery-reared Atlantic salmon smolts. Appl Environ Microbiol 60:3874-3877

Pedersen K, Dalsgaard I, Larsen JL (1996) Characterization of atypical Aeromonas salmonicida isolates by ribotyping and plasmid profiling. J Appl Bacteriol 80:37-44

Reed KC, Mann DA (1985) Rapid transfer of DNA from agarose gels to nylon membranes. Nucleic Acids Res 13: 7207-7221

Sambrook J, Fritsch EF, Maniatis T (1989) Molecular cloning: a laboratory manual, 2nd edn. Cold Spring Harbor Laboratory Press, Cold Spring Harbor

Teska JD, Cipriano RC, Schill WB (1992) Molecular and genetic characterization of cytochrome oxidase-negative Aeromonas salmonicida isolated from coho salmon (Oncorhynchus kisutch). J Wildl Dis 28:515-520

Towbin H, Staehelin T, Gordon J (1979) Electric transfer of proteins from polyacrylamide gels to nitrocellulose sheets: procedure and some applications. Proc Natl Acad Sci USA 76:4350-4354

Trust TJ, Noonan B, Chu SJ, Lutwyche P, Umelo E (1996) A molecular approach to understanding the pathogenesis of Aeromonas salmonicida-relevance to vaccine development. Fish Shellfish Immunol 6:269-276

Whittington RJ, Djordjevic SP, Carson J, Callinan RB (1995) Restriction endonuclease analysis of atypical Aeromonas salmonicida isolates from goldfish Carassius auratus, silver perch Bidyanus bidyanus, and greenback flounder Rhombosolea tapirina in Australia. Dis Aquat Org 22: 185-191

Wiklund T, Dalsgaard I, Eerola E, Olivier G (1994) Characteristics of 'atypical', cytochrome oxidase-negative Aeromonas salmonicida isolated from ulcerated flounders (Platichthys flesus (L.)). J Appl Bacteriol 76:511-520

Submitted: July 17, 2001; Accepted: October 19, 2001

Proofs received from author(s): April 26, 2002 